\title{
Mitigating Strategy of Cyber Crime for Indonesian National Police
}

\author{
Maltha H.S., Suradinata E., Djaenuri M.A., Lukman S
}

\begin{abstract}
This study aims to determine the level of professionalism of the performance of the National Police Apparatus and find a strategy to improve the professionalism of the Indonesian Police based on information technology in dealing with cyber-crime. The approach used in this study was descriptive qualitative, where the research informants were 2 representatives from the National Police, Ministry of Communication and Information Officials and community leaders respectively. Data sources were obtained from the results of interviews, FGDs and observations where data were analyzed using the ASOCA approach (Ability, Strength, Opportunity, Culture and Agility). ASOCA analysis is used to determine the strategy of the National Police in handling Cyber Crime. The results of the study indicate that the resources of the Indonesian Police apparatus in dealing with cyber-crime are not professional. This is indicated by various obstacles faced by the national police, both technical and non-technical obstacles. The results of the ASOCA analysis show that there are six strategies related to the priority of cyber crime mitigation. All six strategies proposed should be accommodated by POLRI national police to support successful programs for mitigating impact of cyber-crime in Indonesia.
\end{abstract}

Index Terms: Cyber Crime, Information Technology, Strategy, ASOCA.

\section{INTRODUCTION}

The emergence of cyber-crime could not be separated from the development of human civilization when entering the era of globalization, accompanied by the development of information and communication technology. Alvin Toffler (1981), predicts that there are three waves of change in civilization in government, namely [1]: First wave of agricultural technology civilization (800 BC-1500); Wave II of industrial technology civilization (1500-1970); and Wave III information civilization (1970-present). Civilization of information can be seen from people's behavior making information one of the necessities of life. Information civilization creates convenience as information media are integrated with each other. Newspaper media is integrated with the internet through online media (new media), so that everyone has the opportunity to deliver news, criticism or aspirations through personal blogs, share on the web or services on the internet. Information technology is applied with the internet developing in all fields such as e-banking, ecommerce, e-government, e-learning, e-library and so on. The cyber crime in Indonesia is the culprit not only

Indonesian citizens, but foreigners who are both domestic and foreign. Police officers managed to capture the network of cyber fraud in the Tanjung Morawa area, Deli Serdang, North Sumatra. 78 foreign nationals consisting of 54 Chinese citizens and 24 Taiwanese were arrested for allegedly committing fraud through the internet with a turnover of 13 billion rupiahs per month [2]. The development of Information and Communication Technology (ICT) is so fast, has a positive impact on the development of science and technology and technological innovation, but the negative impact is in the form of national security threats. In Indonesia, there are three, namely transnational crime (the spread of drugs, drugs, trafficking), terrorism and cyber-crime. What is dangerous is cyber-crime where someone can influence others without being restricted by the state [3]. The rapid development of cyber-crime is less balanced by the provision of Indonesian National Police (POLRI) resources both in quantity and quality. Based on empirical data, the number of POLRI officers is currently 438,000. The population according to the Directorate of Population and Civil Registration, Ministry of Home Affairs as of June 1, 2018 was 262,380,678 people. Comparison of police resources with a population of 1: 599. Based on the provisions in Southeast Asia the ideal ratio is 1: 500. So in quantity the number of POLRI members is still lacking. Likewise in quality, POLRI officials are still low in understanding of information technology because $70 \%$ of high school education personnel are senior high school graduates. Likewise the development in training where a lot of education and training is only administrative [4]. Based on the problems described, in dealing with the rampant cyber -crime, high professionalism is needed from the police officers. This can be realized by continually increasing the quality of POLRI resources both in quantity and quality. Thus it needs to be formulated in this research, namely what strategies should be taken to improve the professional police apparatus in handling cyber-crime, especially in Indonesia. In other words, this study aims to study, analyze and describe Human Resources Management, Recruitment of Employees, and Human Resource Development in the perspective of empowering Indonesian Police resources in the professional scope of handling cyber-crime.

The theoretical contribution of this research is to contribute to the development of Government Science, especially the aspect of increasing professionalism in dealing with cyber-crime; while the practical contribution is in the form of recommendations for the National Police in improving the professionalism of the National Police apparatus in dealing with cyber-crime, material for the Assessment Center and input into policy making.

\section{RELATED WORKS}

\section{A. Management of Government and Human Resources}

Dessler said that human resource management is the application of a policy that is needed by a leader to mobilize his subordinates, including: recruitment, screening, training, rewarding, and valuation [5]. Dessler's view of management is not only limited to the use of other people's energy, but includes the recruitment of employees. After work, it is

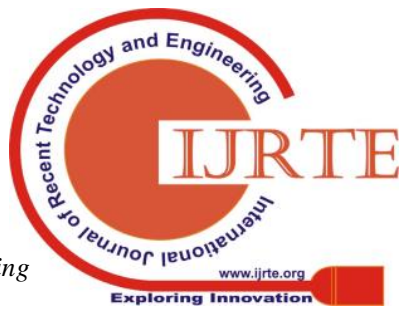


fostered through training in developing the potential of employees [5]. Referring to Dessler's view, there needs to be a paradigm shift in the mindset of members of the Indonesian National Police who deal with cyber-crime. In dealing with cyber-crime before deciding on a problem, they should think carefully and hold on to professional values, and be decided based on reality in the field. This is in line with Khasan Effendy's thinking, where in the paradigm is a set of assumptions about reality that exist according to reality in the field. In other words, the paradigm is the model accepted by the National Police Apparatus in carrying out their duties properly so that the results will be better than other devices [6].

\section{B. Human Resource Recruitment and Development}

According to Dubois and Rotwell, recruitment is the process of attracting as many qualifications as possible for vacancies that exist and are not anticipated. This is talent search, pursuit of the best group of applicants [7]. Efforts to get quality resources adhere to the policy of the National Police Chief Number 10 of 2016 concerning Acceptance of Candidates for Members of the Indonesian National Police. Through recruitment, prospective members are expected to meet their needs with the right principle, on the right place, at the right time [8]. Nadler in detail describes the area of human resource development, as follows: employee training, employee education, employee development and non-employee development. The development of human resources is the most effective way to anticipate the backwardness of the competence of members of the Indonesian National Police and efforts to increase POLRI members who are professional in facing cyber-crime.

\section{METHODS}

The research conducted was qualitative descriptive research involve data sources which are primary data, through interviews with Police officials, Ministry of Communication and Informatics, and the community; and secondary data such as bibliography, government regulations, social media and documentation. The technique of collecting data is by using interview, observation and documentation. ASOCA approach is used to determine the mitigating strategy of cyber-crime by Indonesian National Police through analyzing the professionalism of human resources based on criteria of Ability, Strength, Opportunity, Culture and Agility (ASOCA) [9]. Data analysis with ASOCA Analysis includes: Strategic Environmental Analysis, Internal Environmental Analysis, External Environmental Analysis, ASOCA Strategy Formulation Matrix and Working Program. The results of the ASOCA analysis in the form of new findings in the form of Strategies and Working Programs to improve the professionalism of the Police Apparatus based in Information Technology in dealing with cyber crime.

\section{RESULT \& DISCUSSIONS}

\subsection{Professionalism Analysis of National Police Apparatus Resources}

The following are data from interviews, observations and FGDs related to the professionalism of the police apparatus resources, namely:

\section{A. Interview Result}

The result of interview consist of four findings such as social media users tend to increase. Based on data from Internet World of Statistics [10] and Social Memos [11], the number of social media facebook and twittter users of June 2018 reached 117 million (45\% of the population of 262.380 .678 people) [12]. The negative function of social media consists of spreading pornography, violence, fraud, defamation, theft of data, and utterances of hatred [13]. Second, Indonesian internet users in 2016 reached 132.7 million and 2017 to 143.26 million. The results of Abji's study, users of mobile connections accounted for an outstanding number of 415.7 million as of February 2017 [13]. Cyber -crime is very dangerous for the country because its aspects are very broad (ideological, political, social, economic, defense and security aspects). Third, the rapid development of information technology is reasonable, because of the millennial era. Many victims of cyber-crime active internet users must be careful and develop technological knowledge to avoid negative effects. The last finding that the number of quality and quantity of human resources that handles cyber-crime is still lacking, and the ability of supporting facilities is not yet level in developed countries.

\section{B. Observation Result}

The results of observations on the performance of members of the National Police in charge of handling cyber-crime, there are 5 (five) functions of the National Police, namely: organizers of security and public order, enforcing the law, providing protection, providing protection, and providing services. The five functions are seen when dealing with cyber-crime, not yet fully acting professionally. According to Muarif (2018), the National Police are still unable to appear as professional police [14]. Police professionalism will not occur without the support of police modernization. Modern police are an integral part of modernity that occurred in the era of globalization. Some efforts that must be made open new innovations that are modernity in the field of public services.

\section{FGD Result}

The price of a smartphone is cheap and easy to obtain. Digital communication is fast developing, causing the crime of e-commerce, ATM machine burglary and so on. The role of the National Police is very important in relation to cyber-crime, both in the preventive, curative and education roles. Because of this, the capacity of members of the National Police continues to be improved. In the recruitment of technological capabilities prospective police officers are considered, because it is prone to crime through the internet.

Data triangulation in this study could be shown in Figure 1 below:

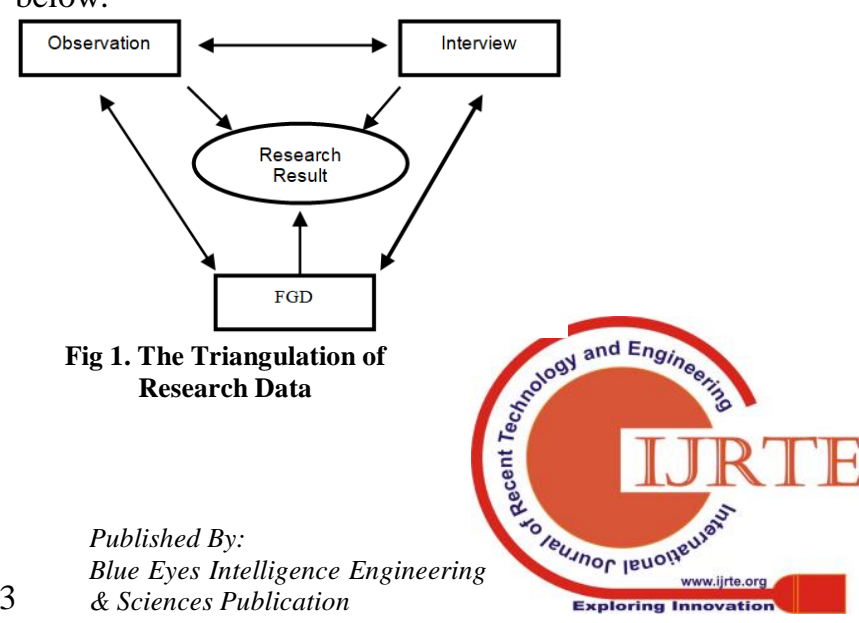


The results of the triangulation concluded that the performance of POLRI members in dealing with cyber-crime was not professional where professional POLRI members should be members of the Indonesian Police who possessed the skills and knowledge in the field of information and communication technology so that they could support the performance of the Police in dealing with cyber-crime.

\subsection{Analysis of Increasing Professionalism of the National Police}

The strategic environment analysis includes both of the internal environment and external environmental analysis. The internal environment factors consists of ability, strength and agility while the external environments factors consists of opportunities and culture. The internal environmental analysis could be shown in Table 1 . The analysis result of Ability $(\mathrm{Ab})$ factors related to cyber-crime mitigation strategy includes POLRI resources factors.

Table 1. Strategic Internal Environmental Analysis

\begin{tabular}{|c|c|c|c|c|c|}
\hline Internal Environment & $\mathbf{A}$ & $\mathbf{S}$ & O & C & $\mathbf{A}$ \\
\hline $\begin{array}{l}\text { 1. Factors in POLRI Resources } \\
\text { a. Quality and quantity improved } \\
\text { b. Work motivation is quite high } \\
\text { c. Understand vision, mission, priority } \\
\text { programs and commitments. } \\
\text { d. Low work innovation } \\
\text { e. Can control emotion } \\
\text { f. Acting effectively and efficiently } \\
\text { g. IT mastery is not maximal }\end{array}$ & $\begin{array}{l}\mathrm{x} \\
\mathrm{x} \\
\mathrm{x} \\
\mathrm{x}\end{array}$ & $\begin{array}{l}\mathrm{X} \\
\mathrm{X}\end{array}$ & & & $\mathrm{X}$ \\
\hline $\begin{array}{l}\text { 2. Infrastructure Factors } \\
\text { a. Limited IT infrastructure }\end{array}$ & & $\mathrm{X}$ & & & \\
\hline $\begin{array}{l}\text { 3. Budget Factors } \\
\begin{array}{l}\text { a. } \\
\text { Budget based on estimation of } \\
\text { activities } \\
\text { b. The lack of training budget }\end{array}\end{array}$ & & $\begin{array}{l}X \\
X\end{array}$ & & & \\
\hline $\begin{array}{l}\text { 4. Information Factors } \\
\text { a. IT support is still limited } \\
\text { b. There is no application for information } \\
\text { that makes the pride of the National } \\
\text { Police } \\
\text { c. Some work processes are still manual }\end{array}$ & & $\mathrm{x}$ & & & $\begin{array}{l}\mathrm{X} \\
\mathrm{X}\end{array}$ \\
\hline $\begin{array}{l}\text { 5. Factors of Capacity Building } \\
\text { a. Low work ethic } \\
\text { b. There are still many disciplinary } \\
\text { violations } \\
\text { c. There are still many ethical violations } \\
\text { d. There is reward and punishment }\end{array}$ & $\mathrm{X}$ & $\mathrm{x}$ & & & $\mathrm{X}$ \\
\hline $\begin{array}{l}\text { 6. Organizational and Management Factors } \\
\text { a. Complete organizational structure } \\
\text { b. Have a vision and mission } \\
\text { c. Have priority programs and } \\
\text { d. Programmed work planning }\end{array}$ & & $\begin{array}{l}\mathrm{X} \\
\mathrm{X} \\
\mathrm{X} \\
\mathrm{X}\end{array}$ & & & \\
\hline $\begin{array}{l}\text { 7. Regulatory Factors } \\
\text { a. The existence of member performance } \\
\text { regulations } \\
\text { b. There is no standard and operating } \\
\text { procedure of cyber crime }\end{array}$ & & $\mathrm{X}$ & & & \\
\hline
\end{tabular}

Thus the priority indicator of Ability (Ab) are IT mastery is not maximal and low work innovations. The analysis result of Strength (S) factors related to cyber-crime mitigation strategy include Infrastructure factors, Budget and Information factors. Thus the priority indicator of Strength $(S)$ are limited IT infrastructure, lack of IT training budget and limited IT support. The analysis result of Agility ( $\mathrm{Ag}$ ) factor related to cyber-crime mitigation strategy include information factors. Based on Table 1, the priority indicator of Agility (Ag) are there are no application for information that makes pride of national police and some work processes still manual.

\begin{tabular}{|c|c|c|c|c|}
\hline External Environment & $\mathbf{A}$ & $\mathbf{S}$ & $\mathbf{O}$ & C \\
\hline $\begin{array}{l}\text { 1. Political factors } \\
\text { a. Neutrality does not favor one party } \\
\text { b. Upholding democracy \& human } \\
\text { rights }\end{array}$ & & & $\begin{array}{l}X \\
X\end{array}$ & \\
\hline $\begin{array}{l}\text { 2. Economic Factors } \\
\text { a. The people's purchasing power } \\
\text { towards ICT increases } \\
\text { b. Internet users are increasing }\end{array}$ & & & $\mathrm{X}$ & $\mathrm{X}$ \\
\hline $\begin{array}{l}\text { 3. Community or social factors } \\
\text { a. Social changes occur } \\
\text { b. Transportation and online shopping } \\
\text { c. A more consumptive lifestyle } \\
\text { d. Free information dissemination } \\
\text { e. Changes in the quality of the } \\
\text { population }\end{array}$ & & & $\begin{array}{l}X \\
X\end{array}$ & $\begin{array}{l}X \\
X \\
X\end{array}$ \\
\hline $\begin{array}{l}\text { 4. Technological factors } \\
\text { a. Low Use of IT in service } \\
\text { b. IT won't makes it easy to complete } \\
\quad \text { work } \\
\text { c. Eroding the culture of corruption }\end{array}$ & & & $\begin{array}{l}X \\
X\end{array}$ & $\mathrm{X}$ \\
\hline $\begin{array}{cl}\text { Culture Factor } \\
\text { a. } & \text { Modernization of information } \\
& \text { systems, transportation and } \\
& \text { community shopping } \\
\text { b. Instant service culture } \\
\text { c. Low transparent, accountable and } \\
\text { democratic cultural culture }\end{array}$ & & & & $\begin{array}{l}X \\
X\end{array}$ \\
\hline
\end{tabular}

Table 2 above show the result of strategic analysis of external environment. The analysis result of Opportunity (O) factors related to cyber-crime mitigation strategy is Technology factors. Thus, the priority indicator of Opportunity $(\mathrm{O})$ are low use of IT in services and IT won't make it easy to complete work. The last factors is about Culture factors. Based on Table, it could be shown that the analysis result of Culture (C) related to cyber-crime mitigation strategy is only Culture factors, which priority indicator are instant service culture and low transparent, accountable and democratic cultural value.

Based on the ASOCA analysis conducted above, there are total six strategies concluded to mitigate cyber-crime according to POLRI professionalism shown in Table 3 : 
Table 3. Strategy Analysis Based on ASOCA

\begin{tabular}{|c|c|c|c|}
\hline $\begin{array}{r}\text { Internal } \\
\text { factors }\end{array}$ & $\begin{array}{l}\quad \text { Ability (Ab) } \\
\text { 1. ICT matery is } \\
\text { not maximal. } \\
\text { 2. Low work } \\
\text { innovations }\end{array}$ & $\begin{array}{l}\quad \text { Strength (S). } \\
\text { 1. Limited ICT } \\
\text { infrastructure. } \\
\text { 2. Lack of } \\
\text { Training Budget } \\
\text { 3. Limited IT } \\
\text { Support }\end{array}$ & $\begin{array}{l}\quad \text { Agility (Ag) } \\
\text { 1. There is no } \\
\text { application for } \\
\text { information to be } \\
\text { the pride of the } \\
\text { National Police. } \\
\text { 2. Some work } \\
\text { processes are still } \\
\text { manual }\end{array}$ \\
\hline $\begin{array}{l}\begin{array}{l}\text { Opportunities } \\
\quad(\mathbf{O})\end{array} \\
\text { 1.Low Using ICT } \\
\text { in service. } \\
\text { 2.ICT won't } \\
\text { makes it easy to } \\
\text { get the job done. }\end{array}$ & $\begin{array}{l}\text { Strategy: Ab-O } \\
\text { 1.Maximize the use } \\
\text { of ICT in public } \\
\text { services. } \\
\text { 2.Take advantage } \\
\text { of member work } \\
\text { innovations to } \\
\text { complete work. }\end{array}$ & \begin{tabular}{l}
\multicolumn{1}{c}{ Strategy: S-O } \\
1.Improve the \\
quality and \\
quantity of ICT to \\
support public \\
services. \\
2.Increase ICT \\
infrastructure to \\
support work.
\end{tabular} & $\begin{array}{l}\text { Strategy: Ag-O } \\
\text { 1.Create a public } \\
\text { service application } \\
\text { that can lead to the } \\
\text { pride of the } \\
\text { National Police. } \\
\text { 2.Create a work } \\
\text { process by } \\
\text { utilizing ICT }\end{array}$ \\
\hline $\begin{array}{l}\quad \text { Culture }(\mathbf{C}) \\
\text { 1.Instant service } \\
\text { culture. } \\
\text { 2.Low } \\
\text { transparent, } \\
\text { accountable \& } \\
\text { democratic } \\
\text { culture. }\end{array}$ & $\begin{array}{l}\text { Strategy: Ab-C } \\
\text { 1.Maximize the use } \\
\text { of ICT as a fast } \\
\text { service culture; } \\
\text { 2.Utilizing } \\
\text { innovation creates } \\
\text { a transparent, } \\
\text { accountable and } \\
\text { democratic culture. }\end{array}$ & $\begin{array}{l}\text { Strategy: S-C } \\
\text { 1.Improve the } \\
\text { quality and } \\
\text { quantity of ICT to } \\
\text { create a fast } \\
\text { service culture. } \\
\text { 2.Improve ICT } \\
\text { infrastructure to } \\
\text { support a } \\
\text { transparent, } \\
\text { account-table and } \\
\text { democratic } \\
\text { culture. }\end{array}$ & $\begin{array}{l}\text { Strategy: Ag-C } \\
\text { 1.Create a public } \\
\text { service application } \\
\text { that is the pride of } \\
\text { the National } \\
\text { Police. } \\
\text { 2.Create a work } \\
\text { process using ICT } \\
\text { with a transparent, } \\
\text { accountable and } \\
\text { democratic work } \\
\text { culture. }\end{array}$ \\
\hline
\end{tabular}

Based on the Table 3 above, all six strategies proposed in this this research should be the priority of POLRI national police in order to build programs for mitigating cyber-crime issue in Indonesia.

\section{CONCLUSION}

Based on the results of the research conducted, it can be concluded that at present the resources of the POLRI national police are not professional yet because they have not met the requirements both internally and externally. Therefore, some efforts to improve the professionalism of police must deal with new innovations especially in the domain of cyber-crime. There are six strategies proposed in this research based on ASOCA approach related to increase the professionalism of POLRI national police in mitigating the impact of cyber-crime. All strategies should be implemented by POLRI to build successful programs for cyber-crime issues in Indonesia.

\section{REFERENCES}

1. M.N. Rosita. (1981), Gelombang Peradaban Manusia dan Perkembangan Teknologi Komunikasi (Alvin Toffler). Available: http://edukasi.kompasiana.com.

2. Media Indonesia. (2017). Kejahatan Dunia Maya. Media Indonesia

3. D. Luthfi. (2018). "Menkominfo: TIK Dapat Mengancam Keamanan Nasional,".

Available: https://www.uinjkt.ac.id/id/menkominfo-tik-dapat-mengancam-keaman an-nasional/\#more-3585.

4. Kompasiana. (2018). "Dampak Media Sosial Terhadap Ketahanan Nasional," Available: https:// www.kompasiana.com/niayolavenia/5615ca6a8e7e613705685882/dam pak-media-sosial- terhadap-ketahanan-nasional.

5. P.S. Lijan. (2016). Manajemen Sumber Daya Manusia: Membangun Tim Kerja yang Solid untuk Meningkatkana Kinerja. Jakarta: PT. Bumi Aksara, 8-9.

6. E. Khasan (2010). Sosiologi Pemerintahan. Bandung: CV. Indra Prahasta, 37.
7. T. Effendi, "Efektivitas Kelembagaan dan Strategi Penataan Lembaga Non-Struktural." in Himpunan Jurnal Negarawan Terpilih, vol. 18, 2010.

8. R.P. Hutagalung, "Democratic Policing Manivestasi Independensi Polri dan Implementasi Perubahan Lingkungan Strategis di Era Demokrasi" in Jurnal Keamanan Nasional, vol. 3, issue 2, 2017.

9. E. Suradinata. (2013). Analisis Kepemimpinan - Strategi Pengambilan Keputusan. Sumedang: Alqaprint Jatinangor.

10. Internetworldstats. (2016), Internet Usage and World Population Statistics. Available: http://www.internetworldstats.com.

11. Socialmemos (2016), Jumlah Pengguna Internet di Indonesia Available: http://socialmemos. com.

12. Data (2018), Jumlah Data Penduduk Indonesia. Available: http://data.go.id/dataset/.

13. K. Nisa, "Dampak Positif Dan Negatif Sosial Media Terhadap Pendidikan Akhlak Anak (Studi Kasus di SMP Negeri 2 Kelas VIII Banda Aceh), in Jurnal Edukasi Mahasiswa Pascasarjana Universitas UIN Ar-Raniry Banda Aceh, vol. 2, issue 1. 2016.

14. S. Muarif .(2018). Polisi Era Kini. Jakarta: Indonesia Press, 99. 